\title{
Chapter 2 \\ The Balkan Gurbet: Traditional Patterns and New Trends
}

\author{
Petko Hristov
}

The tradition of temporary labour migrations, particularly among men, has existed for centuries in a number of regions of the Balkans. The model by which men earn money somewhere 'away' or 'abroad', ${ }^{1}$ but invariably return to their home places and families 'here', is known in different Balkan languages as gurbet, kurbet, or kurbéti and by the South-Slavic term pečalbarstvo ${ }^{2}$ (Hristov 2008a, p. 217). Even though in the Balkans the term gurbet unifies a wide range of labour mobility patterns, these all relate to what Baldwin-Edwards (2002, p. 2) has called 'old-fashioned temporary migration', 'where the migrant's identity is closely linked to the country of origin' and remains significant for extended periods, regardless of ethnic and religious affiliation. The Balkans offers a remarkable variety of such traditional patterns: from the seasonal mobility of shepherds, agricultural workers and master builders to the temporary absences from home of crafts people and merchants (usually for one to three years, typically three ${ }^{3}$ ), with the goal of gaining wealth and supporting family back home. The names of these patterns are diverse, as are their distinctive characteristics in different regions, but all share a number of features that make them an important part of what we could call a Balkan 'culture of migration', following Brettell (2003, p. 3).

Migration researchers interested in the Balkans, however, confront several difficulties. First of all, there is the difficulty of uncovering the reasons for a country's different social groups' labour migrations, internally or to another country. Then

\footnotetext{
${ }^{1}$ The 'abroad' could be a neighbouring region, the big city, another state/country, or 'somewhere in the Balkans'.

2 The word gurbet in most Balkan languages comes from the Turkish-Arabic gurbet, meaning 'abroad' (see Turkish-Bulgarian Dictionary, Bulgarian Academy of Sciences, Sofia 1952, p. 193), and the South-Slavic word pečalbarstvo comes from the Slavic pečalba ('gain'), i.e., to 'gain for a living'.

${ }^{3}$ Sometimes up to seven (see Brailsford 1906, p. 51 for Macedonia).
}

\footnotetext{
P. Hristov $(\bowtie)$

Institute of Ethnology and Folklore Studies with Ethnographic Museum, IEFSEM-BAS, Sofia Bulgaria e-mail: hristov_p@yahoo.com

(C) The Author(s) 2015. This book is published with open access at SpringerLink.com $\mathrm{H}$. Vermeulen et al. (eds.), Migration in the Southern Balkans, IMISCOE Research Series, DOI 10.1007/978-3-319-13719-3_2
} 
there are difficulties in tracing the mechanisms of the process. Finally, there is the difficulty of determining how changes in these processes are reflected in the migrants' everyday life and culture. From a Balkan perspective, both historical and contemporary interdisciplinary research are hampered by the frequent politicization of migration movements, especially concerning refugees and political emigrants. In this respect, Balkan researchers have fallen victim to the tendency of international migration to be a focus of political debate, rather than an analysis of hidden dynamics and socio-cultural characteristics (Kearney 1997, p. 324). Furthermore, if assumptions are correct about the highly problematic and uncertain nature of today's data and interpretation of numbers regarding Balkan temporary migrations (Baldwin-Edwards 2006, p. 9), what must this imply about numbers and interpretations in a historical context?

Patterns of labour migrations in many regions of the Balkans have for centuries followed their traditional model and principles of social organization, the latter being closely interwoven with family and kin. Given this peculiarity, as well as the lack of historical statistical information on seasonal workers in Bulgaria, ${ }^{4}$ Serbia, and the Ottoman Empire, this chapter presents a historic-ethnographic reconstruction of temporary cross-border mobility using predominantly narrative sources. Documents from historical archives (mainly in Bulgaria), memoirs, scattered information from regional research (in Bulgaria, Macedonia, and Serbia), and oral family history narratives are the basic sources drawn upon to study the labour migration traditions of men from the Central Balkan region. All written sources are cited in the text.

Serious difficulties have also arisen from researchers' focus being limited to national frames, particularly among historians. A number of authors who study past labour migrations focus on their own country, writing in their national 'cages' and failing to look across the borders. Social and cultural exchange and influences are often ignored, both in the regions or countries that 'send' migrants and also in those that 'accept' them. Such a view is particularly inaccurate when speaking of the Balkans. In a historical context, labour migrations within the Balkans were as a rule cross-border and trans-border- 'border' in the meaning implied by Barth (1969) of the ethnic, religious, cultural, and later, state boundaries of the Balkans.

This chapter focuses on seasonal and temporary male labour migration (gurbet/kurbet or pečalbarstvo) in its socio-cultural and ethnological aspects, showing its historical roots, specifics, and stages of development, with the example of the Central Balkans See fig. 2.1. This region is the part of the peninsula where today the frontiers of three states come together: the Republic of Bulgaria, the Republic of Serbia and the FYR of Macedonia. The area is known as Šopluk-a denotation without a clearly defined perimeter and including a range of local cultural features (Hristov 2004, pp. 67-82; Malinov 2008, pp. 424-436). In spite of this, the region shows some common and stable cultural traits, even though local populations

\footnotetext{
${ }^{4}$ During the entire period after the liberation of Bulgaria (1878) and World War II, the official state statistics did not take into account seasonal workers hired for less than six months (Natan et al. 1969 , p. 408).
} 
have had different national identities; over the last 140 years parts of this area have changed their state affiliation five times (Hristov 2004, pp. 69-80). National and ethnic groups are not determined once and for all; they change over the course of history and 'by definition are modified after changes in state borders' (Prelić 1996, p. 115). At least, this is the way it has been in the Balkans. Among the stable traits of social life in the Šopluk region during the entire nineteenth and twentieth centuries is the temporary labour migration of the male population, which has shaped the traditional cultural model of local communities. The region under study here has been mentioned only sporadically in previous studies of migration in the Balkans (see Palairet 1987, pp. 225-235).

As a basis for comparison I use materials from my own fieldwork ${ }^{5}$ and historical research on another border region in the heart of the Balkans, famous in the past for its ethnic and religious diversity and for mass labour mobility (seasonal and temporary) of its male population. This is the Mijak $k^{6}$ region in north-west Macedonia, where the state borders of Albania, FYR of Macedonia and the newly proclaimed Republic of Kosovo converge in the present day (see fig. 2.1).

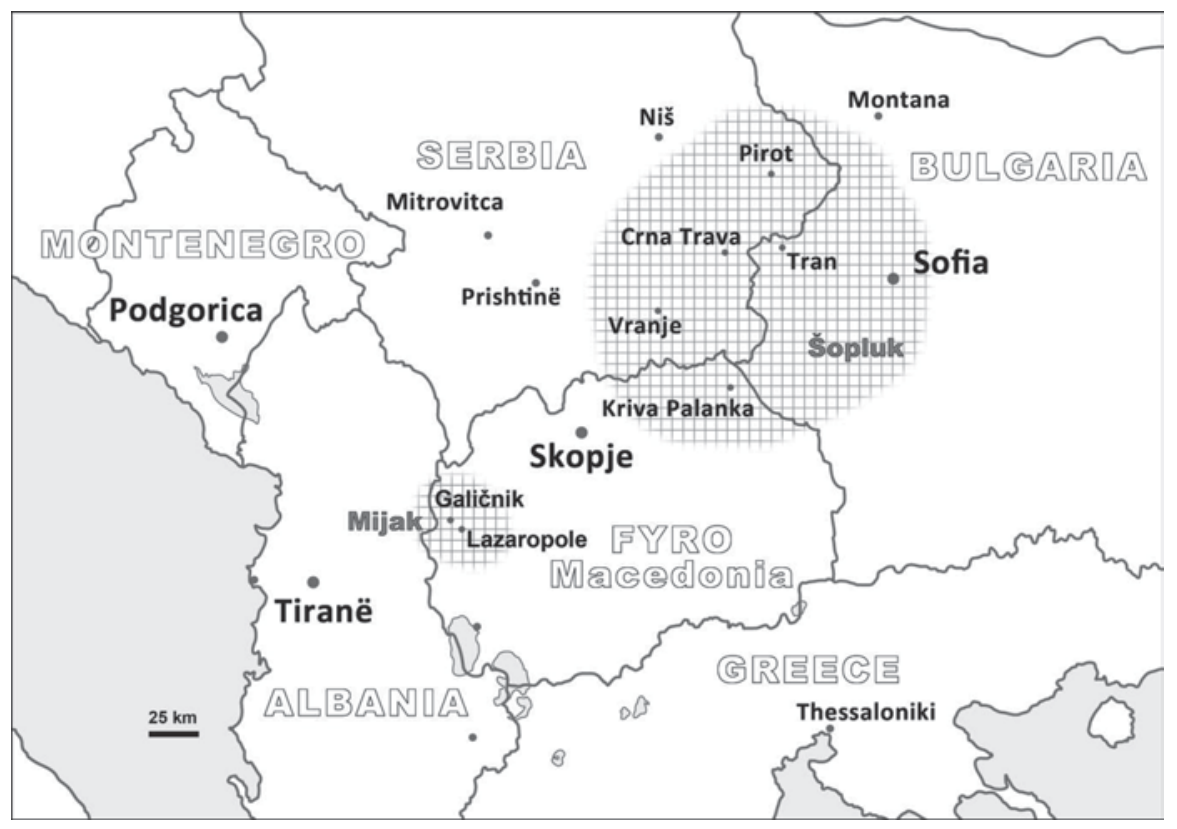

Fig. 2.1 The historic-cultural regions of Mijak and Šopluk

\footnotetext{
${ }^{5}$ I carried out my fieldwork in north-eastern and north-western Macedonia during the summers of 2005 and 2009 (see Hristov 2010a, pp. 141-150).

${ }^{6}$ The Mijaks are a specific ethnographic group, inhabiting north-western Macedonia.
} 


\subsection{Traditions of Labour Mobility}

Traditional patterns of economic migration in the Balkans are impressive in their variety and importance to the social and cultural history of all regions in SouthEastern Europe. Despite the turbulent history of the Balkan peoples-marked throughout the past 200 years by numerous economic and social catastrophesgurbet migration has never ceased and has been accompanied by an exchange of ideas, information, technologies and cultural patterns. For centuries, specific regions of the Balkans in Albania, Bulgaria, Macedonia, northern Greece, Turkey, and south-east Serbia have been the main places for such seasonal or temporary labour migrations, either 'sending' or 'receiving' migrants.

This Balkan version of the 'mobility culture', ${ }^{7}$ practised by generations of men who earned their livelihoods away from home, caused a number of transformations in the entire model of traditional culture in these regions - related to the temporary absence of men from the village. In a number of places, these transformations included the ways of making a living and material culture, as well as everyday gender stereotypes and the division of labour between men and women, social organization, the holiday calendar, and rituals related to a person's life cycle. Some of these cultural patterns and their impact on identity, particularly in the border regions of the Balkans, are discussed in earlier publications (see Hristov 2009a pp. 109-126). Comparative research about gurbet or kurbet in the Balkans is still remarkably scarce. A significant challenge to researchers (historians, ethnologists, anthropologists, sociologists, and demographers) is to explain whether these traditional patterns of 'life in motion' are being reproduced and transformed in the current context of globalization and EU expansion, which give more opportunities for labour mobility from a European perspective. This research has yet to appear. In this regard, the case of Greece is perhaps indicative: it was transformed from being a 'source' of emigrants in the decades after World War II (see Vermeulen 2008) to become an attractive centre for Balkan gurbetchias after 1991. As noted by Baldwin-Edwards and Apostolatou (2008, p. 15), 'Today, immigrants make up around $10 \%$ of the total population'.

\subsection{Past Tradition I: Agrarian and Pastoral Labour Mobility}

Seasonal and temporary labour movement in the Balkans is a social process that developed at varying speeds throughout the nineteenth and twentieth centuries. Within the borders of the Ottoman Empire during the nineteenth century, the main 'streams' of temporary labour migration were headed towards the capital city Stambol (Istanbul) ${ }^{8}$ and the other big cities of the Empire; they also headed to Wallachia

\footnotetext{
${ }^{7}$ I borrowed this term from the French anthropologist Fliche (2006), who studied labour migrations (gurbet) in Turkey.

${ }^{8}$ In 1863, approximately 32,550 Bulgarians worked in Istanbul and its suburbs.
} 
and Serbia (which had already been liberated by that time), to Central Europe and, less frequently, to Asia Minor, Egypt, and Persia.

In the early decades of the premodern age, the main form of seasonal migration in the agrarian sphere was the movement of the labour force from the mountainsareas which, according to Braudel (1998), were characterized by their 'archaism and poverty' - to the rich plains and river valleys, mainly during the harvest seasons ( $n a \check{z} e t v a^{9}$ ). This process is typical for the entire Balkan-Mediterranean range (ibid.: $30,40-43,51-53)$. For example, the main destinations for agrarian seasonal labour mobility from the mountainous central part of the Balkans (the so-called Šopluk) were Wallachia (Vlaško) and the big farms in Dobruđa and the Thracian Valley. During the second half of the nineteenth century, the men from entire villages in the Bulgaria-Serbia border region (e.g., near the Timok River, Godeč, and Berkovica) worked on the farms of Wallachian čokoyas ${ }^{10}$ (Hristov 2010b, p. 199). This type of agrarian labour mobility is not denoted as gurbet and is only sporadically called pečalbarstvo.

Historical patterns of labour mobility that preceded the classic gurbet are represented by transhumant shepherding. Seasonal shepherding and sheep breeding (with a calendar framework between the feasts of Saint George in May and Saint Demetrius in October), along with various combinations of agrarian labour, was commonplace throughout the centuries of the Ottoman Empire and its rule in the Balkans. Enormous flocks of sheep were moved from high mountain pastures to warm southern valleys in winter and back again in early spring. This was usually done by shepherds hired by the wealthy owners (kehayas $\left.{ }^{11}\right)$. Most distinctive was the shepherd nomadism typical not only of Wallachians, Aromanians, and Karakačans, ${ }^{12}$ but also the Bulgarians from the Rodopa Mountains (towards Aegean Thrace and the Upper Thracian Plain) and from the eastern Stara Planina Mountains (towards Dobruđa). Part of this population had the privileged đelepkešan ${ }^{13}$ status of suppliers of the Ottoman army over the centuries (Grozdanova and Andreev 1986, p. 121).

The rich shepherds among the Mijaks in Western Macedonia alternated the summer pastures surrounding Galičnik and Lazaropole with winter pastures on the Salonika Plain. It is no coincidence that one of the best known researchers of labour migrations in the Balkans, Michael Palairet (1987, p. 44), mentions Galičnik as an 'archetypal pečalbar community'. Though this village is currently deserted, in the late nineteenth and early twentieth centuries up to $90 \%$ of its men were away, engaged in gurbet/pečalba in Salonika, Istanbul, Sofia, Belgrade, Bucharest, and even Egypt. A considerable proportion of these temporary migrants owned shops (djukjan) selling dairy products (e.g., milk and white and yellow cheese) and sweets

\footnotetext{
${ }^{9}$ In Bulgaria, this traditional movement from the mountains to the valleys received the folklore name 'slizane na Romanja' ('descending to Romelia', i.e., Thrace).

${ }^{10}$ During the nineteenth century the term 'čokoy' was used to refer to rich owners of arable land in Wallachia.

${ }^{11}$ A traditional name for rich sheep breeders and traders in the Ottoman Empire.

${ }^{12}$ In Greek, they are known as the Sarakatsani.

${ }^{13}$ The official name for rich sheep breeders and traders in the Ottoman Empire, from Turkish-Arabic celep (-bi) - 'flocks and herds trader' - see Turkish-Bulgarian Dictionary, Bulgarian Academy of Sciences Sofia, 1952, p. 75.
} 
in the big cities and capitals of the Balkans, thus creating a market for the products of the famous Mijak kehayas.

Agrarian and pastoral labour mobility had specific age and gender characteristics in the different regions of the Balkans, related both to the peculiarities of agricultural production and market and to the policies of the Ottoman Empire. The female version predominantly involved young, unmarried women ('maidens'). After marriage, the woman traditionally stayed with her family in her husband's house; in the regions with male gurbet, she took care of the family's land and livestock. The Špluk mountain regions were a constant source of seasonal maiden workers, who migrated towards the lowlands (around Sofia in Bulgaria and to Ovče Pole in Eastern Macedonia) at the times of crop harvest. Intensification of agricultural production during the first decades of the twentieth century put an end to this seasonal maiden mobility; yet, the growing needs of the new bourgeois society in the capital forced the rapid development of new types of temporary maiden labour. Being a maidservant in a rich urban family became an important part of the socialization of girls from a number of villages near Sofia (Palairet 1987, p. 34). A twice yearly maidservant market (the Sluginski Pazar) was organized in Sofia, at the piazza where construction workers typically gathered to find work (the so-called 'Dyulgerska Piazza') a week after Saint George's Day and after Saint Demetrius's Day. This became an important location in the capital of Bulgaria after World War I (Hristov 2005, p. 87). Parents brought daughters who were too young for marriage to the market and contracted them out as housemaids. This was usually done by the mothers, who also received the payment for the girls' labour (mainly house and kitchen work). The money was used for the future bride's dowry (see Hristov 2002, pp. 31-32). When the girls reached age 15-16, they were taken back to the village to marry. According to my respondents, girls rarely stayed on to live in the city and marry into urban families. Successful marriages took place in the village, thus marking the end of a young woman's acquaintance with the urban way of life. But the lessons learned from the landlady (gospoža) in the city were taken to the village in the form of cooking recipes, methods of housekeeping and nursing children, and sometimes urban ways of dressing and social etiquette.

These agrarian migrations were ended by the Balkan Wars of 1912-1913 and the new political boundaries that divided and separated the territory of the former Ottoman Empire.

\subsection{Past Tradition II: Seasonal Labour Migration (Gurbet) of Builders}

Crafts people - especially masons - in a number of Balkan mountain regions have a tradition of temporary labour migration lasting from a few months to a few years. Often their seasona $1^{14}$ travels_ — aiming primarily at pečalba ('gain for living') —also

\footnotetext{
${ }^{14}$ Labour mobility of artisans, specifically of builders, had a seasonal character and traditionally spanned the period between Saint George's Day in spring and Saint Dimitri's Day (or Saint Thom-
} 
stemmed from attempts to overcome land shortages in the mountains (Palairet 1987, pp. 225-235; Brunnbauer 2004, pp. 141-142). Labour mobility of artisans had particular characteristics as well, especially among builders, potters, bakers, ${ }^{15}$ and tinkers, whose travels covered the entire peninsula. In this aspect, several regional centres were formed in eastern Albania, Bulgaria, Macedonia, ${ }^{16}$ and in northern Greece (see Nitsiakos 2000, pp. 5-13) which 'emitted' waves of men for gurbet every year throughout the nineteenth and the first half of the twentieth century. Possibly the oldest such centre is north-western Macedonia, specifically the Debar and Tetovo kaaza, which is home to the Mijaks. The other centres - such as Trăn in midwestern Bulgaria, Crna Trava, and Bosilegrad in today's eastern Serbia, and Kriva Palanka and Kratovo in Macedonia - still preserve the tales of the legendary builders (djulgers) of the capitals Belgrade and Sofia who were said to have acquired their skills from Debarlias, originating from the region of Debar (the so-called Arnautluk ${ }^{17}$ ) (Hristov 2008a, p. 219). Traces of the Debarlias can be found among the wandering dyulgers from other regions of Bulgaria - in Bratsigovo in the Rodopa Mountains and in the central Stara Planina Mountains, where the centres were Dryanovo, Tryavna, and Gabrovo. An example of this phenomenon occurred in 1870 when the first railway was built in Bulgaria (between Varna and Rousse). Most workers were 'Christians from Albania who swarm[ed] all over European Turkey and return[ed] home in the winter months, but faithfully returned each year' (Barkley 1876, pp. 56-57).

Traditional seasonal labour migrations of men in Bulgaria and Macedonia are not only part of the centuries-long common history of different ethnic, religious, and language communities of the Balkans. They are also part of folklore (see Karovski 1979; Pistrick 2008, pp. 97-110), of local and family narratives and of the individual biographies of prominent local historical figures, some of which have been celebrated as cultural heroes in tales and legends (Hristov 2008b, pp. 315-323). The intensification of male gurbet in the late Ottoman Empire was caused, in my opinion, by the break-up of the Empire's agrarian system and by the socio-economic crisis of the late eighteenth and early nineteenth centuries that led in the mountain regions to a decline of the well developed and state-maintained network of sheep breeders that supplied the army and large cities (Hristov 2008a, p. 219). This resulted not only in loss of privileges, income, and markets, but also in widespread economic desolation and insecurity in the emigration regions. Furthermore, there was the economic collapse that followed decades of feudal violence at the end of the 18th and the first two decades of the nineteenth century. ${ }^{18}$ Local Mijak folk myth tells a different

as' Day in the central part of Bulgaria) in the autumn, i.e., six to seven months of the year. We call it 'seasonal' to distinguish it from the collective term 'temporary' for traders and other crafts people.

${ }^{15}$ The term 'bakers' includes a range of bakers, pastry cooks, boza-makers, and halva-maker.

${ }^{16}$ The name 'Macedonia' denotes the geographical area Macedonia, which is populated by various communities in terms of confession, ethnicity, language, and culture.

${ }^{17}$ During the centuries of the Ottoman Empire, the name Arnautluk was applied mainly to Albanian-populated regions.

${ }^{18}$ For example, the rule of Kara Feiz, one of the gang leaders of former government soldiers and mutineers - so-called kurđalias - and his son Ali in the Šopluk; and the persistent raids by various villain gangs - called kačaks, especially in Western Macedonia (Petrov 1909, p. 3; Cvijić 1931, p. 134, 162, 169, 199). Kurđalias were a Bulgarian version of 'bandits from the fields', from the 
version, however, relating the beginning of male gurbet at the end of the eighteenth century to the legendary Gjurčin Kokale. Appointed as mayor (kođabašija) of Lazaropole at a young age, Kokale is said to have ruefully witnessed the poor harvests from local lands; one autumn, the story goes, he piled up and set fire to the ploughs of all landowners in Lazaropole, thus 'ordering' the men to become traders and to feed their families by 'earning abroad'19 (Hristov 2008b, p. 318).

In the mountain regions of the central peninsula, gurbet and pečalbarstvo of craftspeople was both widespread and traditionally prestigious (Bobčev 1902, p. 107; Petrović 1920, p. 18; Cvijić 1931, p. 134). This was especially true in the region known as Šopluk: legends are still told of masters who 'could shoe a flea and split the sole leather into nine' (Cvijić 1906, p. 194). The temporary labour migrations of the pečalbars is well documented in the period after the Crimean War (1853-1856). The Austrian vice-consul in Sofia, Von Martrit published a report in 1853 stating, '[T]he Christian citizens of the region around the town of Trăn are so poor they can hardly pay their taxes, therefore in the spring many of them leave their places of origin seeking opportunities to earn money in Istanbul, even Asia Minor. They return as late as winter' (Mihov 1943, pp. 331-332). After the Liberation of Bulgaria in 1878, Konstantin Ireček was reportedly told that 'during the time of the Ottoman Empire, a group of 5,000 men regularly went to Serbia to work as masons in summer'. Later, he added, 'The area around the town of Trăn as well as around Radomir and in Kraište is inhabited by mason-vagrants who work in bunches of 40 to 50 people' (Ireček 1978, p. 559). In the area of Trăn, the seasonal workers in free Serbia were called 'Šumadiers' ( ̌́umadinci) in order to differentiate them from 'Stambolđias' (stambolđii) ${ }^{20}$ working in the villages surrounding the capital of the Empire (Petričev 1940, p. 150).

These masters travelled from early spring to late autumn throughout the Balkan peninsula: from Serbia (Morava region, Šumadia, Belgrade) and Wallachia to Istanbul and Asia Minor (Smirna) as djulgeri (builders), dzidari (masons), ciglari (tile-makers), kaljavci (potters), and crepari (crepnja or podnica, those making flat clay baking pots), and also as stone-cutters from some villages (see Nikolić 1910, p. 29; Mironova-Panova 1971, p. 65; Palairet 1987, pp. 23-46). The seasonal outpouring of mountain male populations ('u pečalbu', meaning 'to gain', and ' $u$ rabotu', meaning 'to work') to other parts of the Balkan peninsula made for stability at a time of complex family households (zadruga ${ }^{21}$ type) and increased the importance of women's position in the family (Brunnbauer 2004, p. 144). However, the deeply-entrenched traditional social role models for men and women in this

Turkish kir — 'field'—cf. Turkish-Bulgarian Dictionary, Bulgarian Academy of Sciences Sofia, 1952.

${ }^{19}$ As told by Trajko Changoski in Lazaropole, the last descendant of Gjurchin Kokale's kin.

${ }^{20}$ Meaning 'people who travel to Šumadia' and 'people who travel to Stambol', respectively.

${ }^{21}$ Zadruga is a South-Slavic term for what social anthropologists call the 'extended family household', when different kin families do not separate but continue to live together in a single household after the sons have married. I agree with Brunnbauer (2004, p. 144) that "the so-called zadruga was the prevalent household pattern only in areas with specific conditions - most notably insecurity and the existence of patrilineages'; this is exactly the case in the regions here under study. 
patriarchal socio-cultural milieu inhibited, to a certain extent, rapid modernization in these pastoral communities. It is a fact, though, that entire villages were left in women's hands for entire seasons. Palairet (2002, p. 173) quotes Ireček, who calls Koprivštica (in Bulgaria) 'a female town during winter'. In addition, men's labour mobility, their seasonal absence from the local village community and their continuous work away from the home region contributed to the great strength of kinship networks in these regions. Even when settled in the big cities some decades later, as refugees after World War I or in the years of accelerated urbanization following World War II, these migrants constructed proverbially efficient social networks for mutual help, based on kin and local origin.

An important condition for the continued preservation and significance of the family and kin structure for the overall life of the village was the traditional organizational form of the migrant groups (pečalbarska tajfa) of construction workers. These were based on the kinship principle and up to the beginning of the twentieth century knew no written regulations (of the guild type). Traditionally, migrant male labour groups followed the norms of customary practice: a hierarchy of masters (majstor), journeymen ( $k a l f a)$, and apprentices (čirak) was selected mainly from among the kin and, rarely, the wider village community. This peculiarity of the social organization of the migrant groups continued for a long period of time, both in Bulgaria and in Macedonia - in some places it remained as late as World War II.

\subsection{Past Tradition III: Cross-Border Labour Mobility}

The directions, destinations, and character of the temporary labour of male migrant groups changed a number of times in the nineteenth and the first decades of the twentieth century along with the turbulent and complicated historical destiny of this part of the Balkans (Manolova-Nikolova 1997, pp. 159-173; Stojančević 1995, pp. 283-331). Before the liberation of Bulgaria in 1878, the most attractive centres for migrant groups from today's border region (Šopluk, including Crna Trava, Trăn, Caribrod, Pirot, Leskovac, Vranje, Lužnica, Kumanovo, Kratovo, and Kriva Palanka) were Šumadija in Serbia and Vlaško (Wallachia) in today's southern Romania). These were already independent and within the boundaries of the Ottoman Empire. Also attractive were the region of Zagore near the towns of Vidin and Lom in the north-western part of today's Bulgaria, Dobruđa in the north-eastern part of today's Bulgaria, and Istanbul, which was the Empire's capital. In their travels across the Balkan peninsula, the skilled master builders left traces of their work everywhere. Examples range from the popular Wallachian houses of rammed earth (bienica or punjenica, see Mironova-Panova 1971, pp. 69-70) to modern buildings in Istanbul and Belgrade and the large port cities of the Ottoman Empire. In a number of (then) border cities in free Serbia (Paračin, Jagodina, and Čuprija) and Wallachia (Craiova, Gjurgiu, Braila, and the capital Bucharest), temporary migrants from Bulgaria and Macedonia established entire communities of their own. Many of them actively participated in the revolutionary struggles, uprisings, and wars that led to the liberation 
of their home regions from Ottoman power, as well as their inclusion within the borders of the new nation states in the Balkans (Hristov 2008a, p. 222).

After the liberation of Bulgaria in 1878, the new capital Sofia quickly became an attractive destination for temporary labour migrants from the central Balkans, including Macedonia. Most of the seasonal construction workers in Sofia were from mountain villages along the Bulgarian-Serbian border and from the regions of Kratovo and Kriva Palanka in Macedonia, which remained within the Ottoman Empire. The most famous construction contractors in the Bulgarian capital were born in Trăn (a western Bulgarian border region) or in Macedonia (Petrović 1920, p. 23). The seasonal construction workers had 'their own' gathering and hiring spot- the Dyulgerska Piazza which was mentioned earlier as the venue of the twice-yearly 'maidservant markets'. It became an important location in the capital city as early as the end of the nineteenth century (Hristov 2005, p. 86). At the beginning of the twentieth century, construction workers were still 'seasonal guests' in the big city: they worked and earned in the capital, but spent winter months in their home villages. Soon after the Ilinden Uprising in Macedonia in 1903 many of these men became refugees from their home regions, arrived in large Bulgarian cities (Sofia, Plovdiv, Varna, and Russe) and with their own communities and separate quarters there. The decades-long destinations of the male pečalbars traced a route similar to that of the refugees from the central part of the peninsula. ${ }^{22}$

Organized on the basis of kinship or local communities, groups of temporary migrants (so-called pečalbarska tajfa) developed their own subculture in the big cities (Istanbul, Thessalonica, Belgrade, and Sofia). The seasonal workers had spots where they congregated, such as the famous 'Znepole'23 hotel (for the pečalbars from Trăn) and the 'Razlog ${ }^{24}$ restaurant (for those from Macedonia) in Sofia. Dialects came to be language markers both in Bulgaria and in Serbia (Cvijić 1922, p. 219). Some groups developed their own 'secret' language, such as the so-called Fornički speech of those from the north-eastern Macedonian village of Šlegovo, near Kratovo (Filipovski and Kitanovski 1984, pp. 67-135). Local populations on both sides of the (political) frontiers also considered the migrant groups from Šopluk to be autonomous communities, and their seasonal moving, from early spring to late autumn, was compared to the flocks of migratory birds: they were called 'cranes' (dialectal kurkavci) (see Hristov 2005, p. 85). These communities of male craftspeople traditionally had a closed subculture. Workers from other regions rarely could penetrate into their construction groups even into the 1940s. ${ }^{25}$

At the beginning of the two Balkan Wars and during World War I, many pečalbars from the central regions migrated to America to avoid military service.

\footnotetext{
${ }^{22}$ Here is only one example: out of 74 construction workers in Sofia from the village of Radibuš (the Kriva Palanka region in present-day FYR of Macedonia), 72 enrolled as volunteers in the 'Macedonian' volunteer corps of the Bulgarian Army to participate in the First Balkan War, hoping to liberate Macedonia (personal fieldwork records).

${ }^{23}$ Znepole is the geographic name of the Trăn Valley in the westernmost part of Bulgaria.

${ }^{24}$ Razlog is the name of a town in Bulgaria, in the geographic area of Pirin Macedonia.

${ }^{25}$ It is still said in Sofia that you can only 'steal' but not learn the craft from the Trăn masters.
} 
As early as the end of the nineteenth century, the USA became an attractive place for the region's unemployed labour force - first for those from Macedonia, and later for those from Bulgaria and Serbia as well (Petrov 1909, pp. 3-6). Some of these 'Americans' returned home in the 1920s, but most remained in the USA.

Time transformed local cultural tradition in the regions with traditional male labour mobility in accordance with the men's seasonal absences from their homes. In Šopluk, the builders' groups (tajfa) started their journey on the days of some of the great spring feasts around Đurđovdăn (Saint George's Day), but traditionally men were solemnly seen off by their families on the first Monday of Long Lent, the so-called Čist Ponedelnik ('Clean Monday'). By mid-May-Saint Constantine and Helen's Day — they were already at work ('u rabotu') (Petrović 1920, p. 14). Their earliest return was around Saint Demetrius's Day or Ranđelovdăn (Saint Michael the Archangel's Day in November). That is why most family and kin feasts (of the svetăc type, the feasts of the family patron saints, see Peševa 1960, p. 739) were grouped in the period from Saint Dimitri's Day to Saint John's Day in January (see Hristov 2001, p. 193). Weddings were similarly concentrated in the winter period, and in this region most children were born in autumn.

Local cultural tradition shows a stable 'migrant' ritual complex, connected with seeing off the groups of men leaving on gurbet. Seeing off the migrants took place in the following way: the oldest woman of the household scattered live coals from the hearth on both sides of the front gate, which the men then had to cross to acquire magical protection. This important ritual is similar to the seeing off given during traditional weddings: when men from the bridegroom's family left their home to fetch the bride and her dowry ( $r u b a$ ), they jumped over live coals from the hearth for magical protection (Mironova-Panova 1971, p. 181). Seeing off the groups of men as they left for gurbet was a ritualistic occasion, involving female tears and wishes for great gain.

In other regions of traditional seasonal labour mobility, the intensity of the yearly feast cycle was reversed. Among the Mijaks in Western Macedonia, weddings were held only once a year, when the young men returned to their homes on the day of the village church celebration (e.g., Saint Peter's Day in Galičnik ${ }^{26}$ and Saint Elijah's Day in Lazaropole). If the young couple (verenici) did not manage to marry on that day, they had to wait an entire year until the next church celebration; the only 'reserve' option allowed by tradition was that of the feasts dedicated to the Virgin Mary (Hristov 2010a, p. 147). As late as the mid-twentieth century, these mountain villages were entirely closed and endogamous; for some the endogamy was intervillage, but in a local circle. Young men returned to their homes to find brides, and weddings as a rule were only 'among their own' (in a village and regional aspect).

\footnotetext{
${ }^{26}$ During the last decades of the twentieth century the Galičnik wedding was transformed into a folklore performance. Even now, however, those who really want to marry in Galičnik can do so in the local church only on Saint Peter's Day. In summer of 2005 on Saint Peter's Day in Galičnik I witnessed three consecutive weddings. Galičnik locals still remember years with more than 30 weddings on this day. Saint Peter is the patron saint of the biggest church in the village, and Saint Peter's Day is the most important feast for the entire village.
} 
Even today local women are said to marry in summer when the descendants of the former pečalbars from Europe, America, and Australia return home to find wives.

Also in these mountain regions of Western Macedonia, a stable gurbet ritual complex developed related to sending off and welcoming back the groups of migrant workers. Women and children would follow their husbands, sons, and fathers far outside the village, to a spot traditionally marked as a boundary of the region, where groups of departing men gathered. One can map these migrant toponyms for each of the villages and regions to create a particular 'landscape of gurbet memory' (Pistrick 2008, p. 103), part of what Nora (2004, p. 37) calls the 'milieux de mémoire' as social and collective memory. The names of these places were often related to 'crying' (such as the Bridge of Crying near Želino, Tetovo region and the Tree of Crying near Lazaropole; see Hristov 2009b, p. 93) and bring to mind touching scenes of (temporary) family separation. Local memory recalls that even the Težkoto dance, traditional in Western Macedonia, was performed at these places as the men started out on their journey.

This gurbet toponymy was not confined to Western Macedonia. Pistrick (2008) found gurbet toponyms in the Zagoria area between Albania and Greece to also be predominantly related to separation. Particularly well-known are the so-called Guri e shkëmbive; these are porous limestone rocks covered with small holes said to have been made by the tears shed by mothers of leaving migrants (ibid.: 103). This reminds us of the famous Sopolivi kamănye ('Rocks of Tears') in the Koprivštica vicinity of Central Bulgaria, described by Ireček (1899, p. 96) in the late nineteenth century. There are other similarly ringing Bulgarian gurbet toponyms like the Oplači kamak ('Stone of Crying'), Plači-mogila ('Hill of Crying') and Plači-topola ('Poplar of Crying'). In this regard, Ireček (1978, p. 48) makes note of the erstwhile well known Kurbet Mountain which separated the Šopluk mountain regions from the Šumadia valley in Serbia. It probably received its name precisely as a location for gurbet separation and reunion.

Gurbet toponyms can be characterized as 'lieux de mémoire' (to use Nora's terms), created by the piling up of collective memories of particular persons and events. As a result, these spatial loci turn into an 'environment of memory' ('milieux de mémoire') and function as elements and pivot points of collective identity. In the future study of cross-border migrations, drawing a 'landscape of gurbet memory' in the Balkans, as part of what Assmann (2001, p. 37) calls collective memory, is part of the challenge that researchers are currently facing.

\subsection{Past Traditions and New Trends}

The new political borders in the Balkans after the Balkan Wars and World War I, the restrictive national legislation in the individual countries, and the complex political environment in most Balkan countries (both victorious and defeated in the wars), further intensified by nationalist propaganda, led to a drastic decrease in trans-border labour mobility of men from the regions studied. Between the two world wars, 
the Balkan market for seasonal trans-border migrants virtually collapsed: the USA closed as 'the pečalbar Eldorado' and the social situation in Bulgaria, the Kingdom of Yugoslavia and Greece drastically reduced opportunities for labour migration (Palairet 1987, p. 34). This led to a change in the model of labour migration among men from these regions. Their movements were redirected towards the big cities at the hearts of their own countries. Still, this labour mobility had the traditional characteristics of gurbet: the men were earning in the city but their families stayed in their home villages throughout the Šopluk where the men spent the inactive winter months. However, this increase of 'internal' temporary labour migration laid the social foundations for permanent emigration to the cities (or urbanization), which became a reality after World War II and was stimulated by the intensive industrialization undertaken by the new socialist governments of Bulgaria and Yugoslavia.

After World War II, the Central Balkans became a region of the new 'People's Republics'. These dramatically changed the labour market situation and character of labour relations in Bulgaria, Serbia and Macedonia. The accelerated industrialization of the 1950s turned the seasonal migrants into 'socialist workers' and resulted in the mass depopulation of villages. The builders became city dwellers, bringing their families to the big cities and gradually losing their connection with the land. Only elderly people remained in the villages. In Bulgaria this contributed to the forced mass collectivization of arable land, which in turn led to the villagers' loss of their land.

The century-long traditional model of male labour mobility (gurbet) underwent further drastic change during the 1960s, when a number of Western European countries invited 'guest workers' from the Mediterranean countries - including Greece, Turkey and Yugoslavia-turning men into legal temporary migrants. A considerable proportion stayed in the host countries and the migration process then continued through family reunification, with most Western European countries successively becoming countries of immigration (Guentcheva et al. 2003). During this period, temporary migrants from the territory of (former) Yugoslavia, Greece, and Turkey settled permanently in Western Europe. The traditional gurbet model of seasonal and temporary migrations and labour outside the region was thus transformed from the beginning of the 1960s into the pečalbar model of the Gastarbeiter culture, especially in Serbia and the FYR of Macedonia.

Actively joining this pan-European process of labour mobility from the early 1990s were Balkan countries, like Albania, Bulgaria, and Romania-which until then had been closed within their centralized economies and state-regulated labour movements. While in the 1990s seasonal and irregular migration had been directed mainly towards neighbouring Greece, at the beginning of the new millennium and especially after the removal of Schengen visa restrictions for Bulgarian citizens, a great number of Bulgarians-Christians and Muslims, Bulgarian Turks as well as Macedonians with Bulgarian citizenship - found themselves drawn into labour migrations of a range of durations to the countries of the EU, especially Germany, Great Britain and Spain. Time will tell whether these migrant workers will adhere predominantly to the circular migration model (see Baldwin-Edwards 2006, p. 9) that has its background in traditional Balkan gurbet, or if these people instead become permanent migrants in the host countries. 
Open Access This chapter is distributed under the terms of the Creative Commons Attribution Noncommercial License, which permits any noncommercial use, distribution, and reproduction in any medium, provided the original author(s) and source are credited.

\section{References}

Assmann, J. (2001). Kulturnata pamet [Das kulturelle Gedächtnis]. (trans: A. Dimova ). Sofia: Planeta 3.

Baldwin-Edwards, M. (2002). Immigration, immigrants and socialisation in southern Europe: Patterns, problems and contradistinctions. Keynote lecture at Academic Symposium on Immigration in Northern versus Southern Europe, Athens, November. www.mmo.gr/pdf/publications/publications_by_mmo_staff/IMMIGRATION\%20lecture\%20NIAv6.pdf. 22.12.2010.

Baldwin-Edwards, M. (2006). Patterns of migration in the Balkans. Mediterranean Migration Observatory Working Paper No. 9. Athens: University Research Institute of Urban Environment and Human Resources, Panteion University. http://aei.pitt.edu/7045/01/mmo_wp9.pdf. 22.12.2010.

Baldwin-Edwards, M., \& Apostolatou, K. (2008). Ethnicity and migration: A Greek story. Migrance, 31, 5-17.

Barkley, H. C. (1876). Between the Danube and Black Sea. London: Murray.

Barth, F. (1969). Introduction. In F. Barth (Ed.), Ethnic groups and boundaries: The social organization of culture difference (pp. 9-38). Oslo: Universitetsforlaget.

Bobčev, S. (1902). Sbornik bălgarski juridičeski običai [A Collection of Bulgarian legal practices] (Vol. II). Sofia: Pečatnica na P. M. Bezajtov.

Brailsford, H. N. (1906). Macedonia: Its races and their future. London: Methuen \& Co.

Braudel, F. (1998). Sredizemno more i sredizemnomorskijat svjat po vremeto na Filip II [The Mediterranean Sea and the Mediterranean world at the time of Philip II] (Vol. I). (trans: V. Ilieva). Sofia: ABAGAR.

Brettell, C. (2003). Anthropology and migration: Essays in transnationalism, ethnicity and identity. Walnut Creek: AltaMira Press.

Brunnbauer, U. (2004). Environment, markets and the state: Human adaptation in the Balkan mountains, 19th to early 20th century. Ethnologia Balkanica, 8, 129-154.

Cvijić, J. (1906). Osnove za geografiju i geologiju Makedonije i Stare Srbije [The basics of the geography and geology of Macedonia and Old Serbia]. Beograd: Srpska Kraljevska akademija.

Cvijić, J. (1922). Balkansko poluostrvo i južnoslovenske zemlje: osnovi antropogeografije [The Balkan peninsula and the land of the southern Slavs] (Vol. 1). Beograd: Knjizarnica Gece Kona.

Cvijić, J. (1931). Balkansko poluostrvo i južnoslovenske zemlje: osnovi antropogeografije [The Balkan peninsula and the land of the southern Slavs] (Vol. 2). Beograd: Knjizarnica Gece Kona.

Filipovski, I., \& Kitanovski, I. (1984). Šlegovskiot taen (furnički) govor [Šlegovo secret language]. Makedonistika, 3, 67-135.

Fliche, B. (2006). Le nomade, le saisonnier et le migrant: Une culture de la mobilité en Anatolie centrale? Etudes Rurales, 1(177): 109-120.

Grozdanova, E., \& Andreev, M.(1986). Bălgariteprez XVIvek. [Bulgarians during the 16th century]. Sofia: Izdatelstvo na OF.

Guentcheva, R., Kabakchieva, P., \& Kolarski, P. (2003). Bulgaria: The social impact of seasonal migration. Migration trends in selected applicant countries 1. Vienna: IOM. www.pedz.unimannheim.de/daten/edz-k/gde/04/IOM_I_BG.pdf.

Hristov, P. (2001). Ahnenkult in Westbulgarien: das Fest des Schutzheiligen. In U. Brunnbauer \& K. Kaser (Eds.), Vom Nutzen der Verwandten. Soziale Netzwerke in Bulgarien (19. und 20. Jahrhundert) (pp. 187-199). Wien: Böhlau. 
Hristov, P. (2002). The "ransom" for the missing virginity of the bride, Makedonski folklor, 60, $25-37$.

Hristov, P. (2004). Granicite na Shopluka i/ili shopi bez granici [Frontiers of "Shopluk" and/or Shops without frontiers]. In B. Sikimić (Ed.), Skrivene manjine na Balkanu [Hidden minorities in the Balkans] (pp. 67-82). Beograd: Balkanološki institut SANU.

Hristov, P. (2005). Places to exchange cultural patterns: The market and the piazza for hired labour in Sofia. Ethnologia Balkanica, 9, 81-90.

Hristov, P. (2008a). Trans-border exchange of seasonal workers in the central part of the Balkans (19th to 20th century). Ethnologia Balkanica, 12, 215-230.

Hristov, P. (2008b). Collective identity and the myth of a local civilizer-hero: Family narratives in modern European perspective. In E. Marushiakova (Ed.), Dynamics of national identity and transnational identities in the process of European integration (pp. 315-323). Cambridge: Cambridge Scholars Publishing.

Hristov, P. (2009a). Borders and identities: Difficulties and perspectives faced by comparative ethnological studies of the border regions on the Balkans. Etudes Balkaniques, 3, 109-126.

Hristov, P. (2009b). Gurbet toponymy. Makedonski folklor, 67, 91-96.

Hristov, P. (2010a). Trans-border migration: The example of Western Macedonia. In A. Krasteva, A. Kasabova, \& D. Karabinova (Eds.), Migrations from and to southeastern Europe (pp. 141-150). Ravenna: Longo Editore.

Hristov, P. (2010b). "Valahia" ca destinaţie importantă a muncit orilor sezonieri (pečalbari) din partea centrală a Balcanilor [Wallachia as an important destination for seasonal workers (pečalbari) from the central part of the Balkans]. In S. Şerban (Ed.), Teme in antropologia socială din Europa de sud-est. Volum dedicate memoriei Profesorului Paul Stahl [Themes in the social anthropology of south-western Europe, in memoriam of Prof Paul Stahl] (pp. 194-295). Bucureşti: Paideia.

Ireček, K. (1899). Knjažestvo Bulgaria [Kingdom of Bulgaria]. Plovdiv: Hristo G. Danov.

Ireček, K. (1978). Istorija na bălgarite [History of the Bulgarians]. Sofia: Bulgarska akademija na naukite.

Karovski, L. (1979). Makedonski pečalbarski narodni pesni [Macedonian pečalbar folk songs]. Skopje: Institut za folklore 'Marko Cepenkov'.

Kearney, M. (1997). Migration. In T. Barfield (Ed.), The dictionary of anthropology (pp. 322-324). Oxford: Blackwell.

Malinov, Z. (2008). The Macedonian shops (Shopi): Borders, identity and perspectives. In E. Marushiakova (Ed.), Dynamics of national identity and transnational identities in the process of European integration (pp. 424-436). Cambridge: Cambridge Scholars Publishing.

Manolova-Nikolova, N. (1997). Sredna Zapadna Bălgaria 1877-1879: Prehodăt meždu dve epohi v Trănsko-Brezniškija kraj [Midwest Bulgaria, 1877-1879: The transition between two epochs in the Trăn-Breznik region]. Rodina, 3-4, 159-173.

Mihov, N. (1943). Prinosi kăm tărgovskata istorija na Bălgarija. Tom II: Avstrijski konsulski dokladi [Contributions to commercial history of Bulgaria, Vol. II. Austrian Consul's Reports]. Sofia: Bulgarska akademija na naukite.

Mironova-Panova, S. (1971). Trănskijat kraj [Region of Trăn]. Sofia: Izdatelstvo na OF.

Natan, Ž., Berov, L., \& Hadžinikolov, V. (Eds.). (1969). Ikonomikata na Bălgarija do socijalističeskata revoljucija [The economics of Bulgaria before the socialist revolution] (Vol. 1). Sofia: Nauka i izkustvo.

Nikolić, V. (1910). 'Iz Lužnice i Nišave’ [From Lužnica and Nišava], Srpski etnografski zbornik 16. Belgrade: Srpska Kraljevska akademija.

Nitsiakos, V. (2000). Singeneia kai scheseis paragoyis sta bouloukia tis Ipeirou [Kinship and relations of production among migrant labour groups of Epirus]. Ethnoloyia, 8, 5-12.

Nora, P. (2004). Mesta na pametta. [Les lieux de mémoire]. (trans: Stojan Atanasov). Vol. 1-2, Sofia: Dom na naukite za čoveka i obštestvoto.

Palairet, M. (1987). The migrant workers of the Balkans and their villages (eighteenth centuryWorld War II). In K. Roth (Ed.), Handwerk in Mittel- und Südosteuropa (pp. 23-46). Munich: Südosteuropa-Gesellschaft. 
Palairet, M. (2002). The Balkan economies c. 1800-1914: Evolution without development. Cambridge: Cambridge University Press.

Peševa, R. (1960). Edin starinen semeen praznik: Praznuvane na svetec v Severozapadna i Zapadna Bălgaria [An ancient family feast: Celebrating the svetec in north-western and western Bulgaria]. In V. Lekov (Ed.), Ezikovedski-etnografski izsledvanija v pamet na akad. Stojan Romanski [Linguistic and ethnographic studies in memoriam of acad. Stojan Romanski] (pp. 731-754). Sofia: Bulgarska akademija na naukite.

Petričev, L. (1940). Trănskite dobrovolci v Srăbsko-Turskata vojna-1876 godina [Tran volunteers in the Serbo-Turkish war of 1876]. In R. Todorov (Ed.), Trănski kraj [Trăn district] (pp. 147-162). Sofia: Druzestvo 'Ruj'.

Petrov, G. (1909). Emigrantskoto dviženie za Amerika v Makedinija [Macedonian emigration to America]. Kulturno edintvo, 7-8, 3-6.

Petrović, J. (1920). Pečalbari, naročito iz okoline Pirota [Pečalbars, particularly from Pirot district]. Belgrade: Tipografija.

Pistrick, E. (2008). Migration memories in the borderlands: The constructions of regional identity and memory in Zagoria (southern Albania) through place and sound. Ethnologia Balkanica, $12,97-110$.

Prelić, M. (1996). Posle Frederika Barta: Savremena proučavanja etniciteta u kompleksnim drustvama [After Frederic Barth: Contemporary research on identity in complex societies]. Glasnik Etnografskog instituta SANU, 45, 101-121.

Stojančević, V. (1995). Srbi i Bugari 1804-1878 [Serbs and Bulgarians 1804-1878]. Novi Sad: Prometej.

Vermeulen, H. (2008). The Greek labour diaspora in Europe. Migrance, 31, 18-36.

Petko Hristov is Associate Professor at the Institute of Ethnology and Folklore Studies with Ethnographic Museum at the Bulgarian Academy of Sciences, Sofia. He is editor of the collections Migration and identity: Historical, cultural and linguistic dimensions of mobility in the Balkans, Sofia: Paradigma, 2012 and co-editor of the book: Labour migrations in the Balkans, MünchenBerlin: Verlag Otto Sagner, 2012. His main scholarly interests involve studying labour migrations in the Balkans, the construction of social networks among trans-border migrants, family and kinship, the construction of identity and political anthropology. http://www.eim-bas.com/profile. $\mathrm{php} ? \mathrm{u}=\mathrm{p} \_$hristov $\& \mathrm{l}=\mathrm{en} 1$ 